\title{
O QUE NOS ESVAZIA
}

Rodrigo de Medeiros Silva ${ }^{1}$

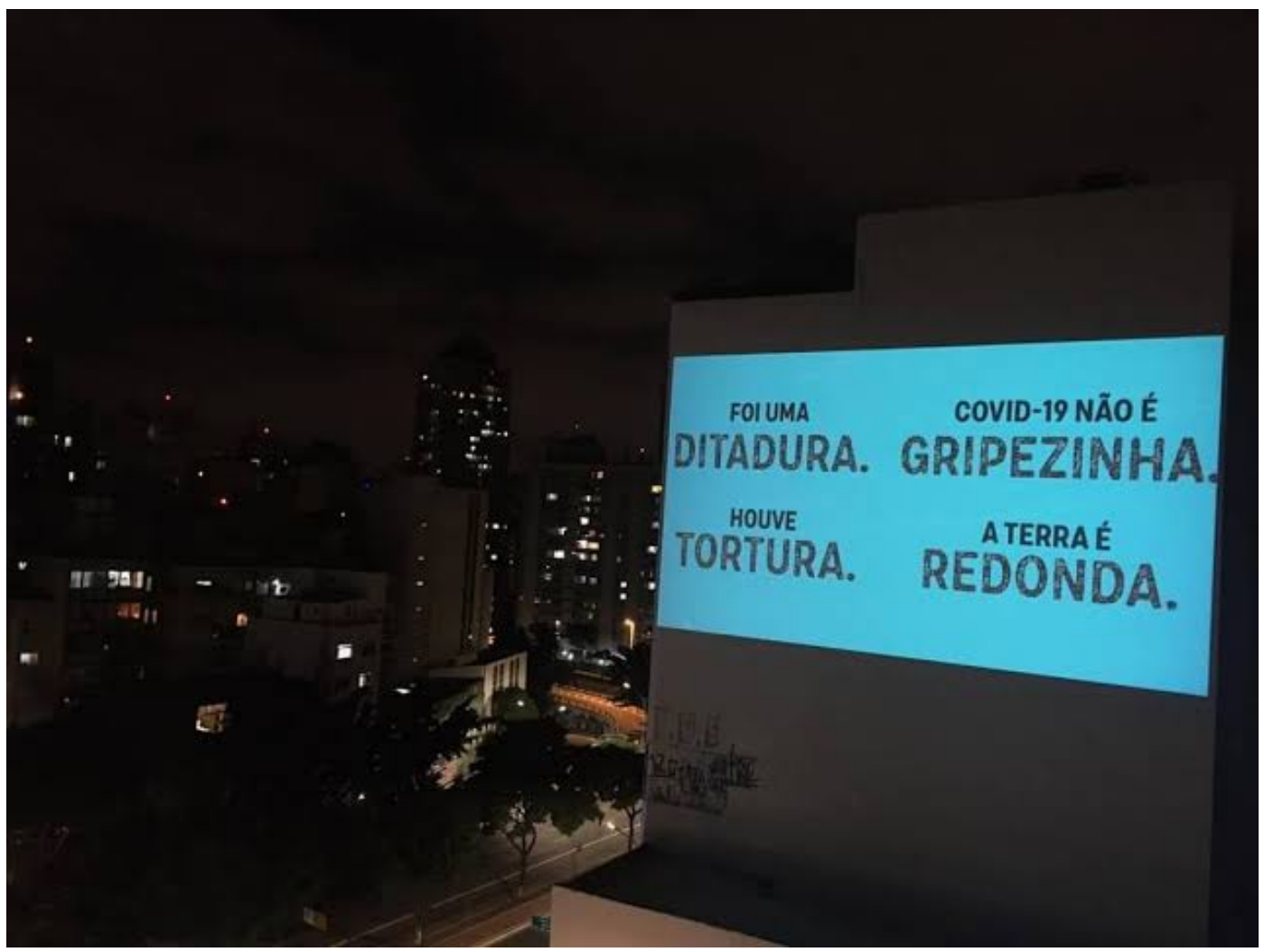

Leis, decretos, portarias, medidas provisórias

Aglomerações, bandeiras, restrições, lockdow...

A pandemia melhor mostrou nosso normal,

Nossas mazelas ficaram mais e mais notórias.

Mas o futebol bem preocupa o jornal,

E o que importa pro Brasil colonial

São os lucros e deles que inventam mil glórias!

De repente, o mundo se vê num só quintal,

Mas as intolerâncias não são mais vexatórias,

Democracias, então, mostram-se ilusórias;

Fechar o comércio é o crime fatal,

1 Doutorando em Direito e Sociedade pela UniLaSalle, mestre em Direitos Humanos pela UniRitter; especialista em Direito Civil e Direito Processual Civil pelo IDC; membro da RENAP e filiado ao IPDMS. 


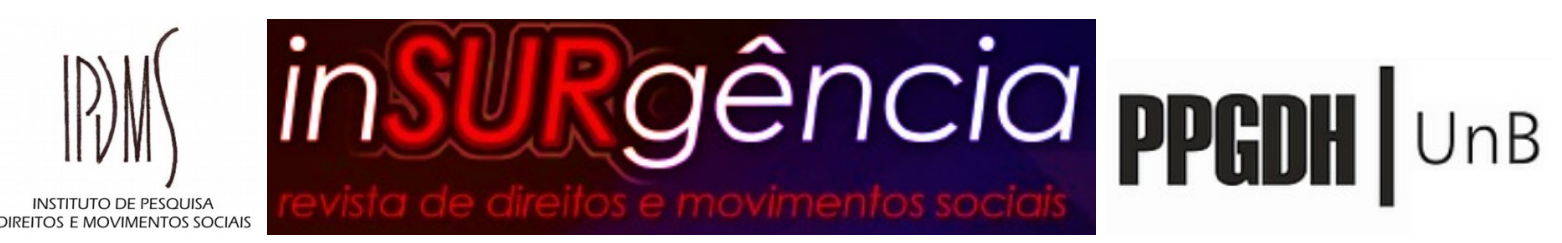

Porque as vidas não são causas inibtórias...

Vazios urbanos...terras vazias...tão irrisórias,

Apenas se for interesse do capital!

This work is licensed under a Creative Commons Attribution 4.0 International License.

Submetido em 18/07/2020.

Aprovado em 18/07/2020. 